\title{
Conodont Geothermometry in Pyroclastic Kimberlite: Constraints on emplacement temperatures and cooling histories
}

\author{
Pell ${ }^{1}$, J., Russell ${ }^{2}$, J.K. and Zhang ${ }^{3}$, S. \\ 1.Peregrine Diamonds Ltd, Vancouver, Canada, jennifer@pdiam.com \\ 2. Department of Earth, Ocean \& Atmospheric Sciences, University of British Columbia, Vancouver, Canada \\ 3. Canada-Nunavut Geoscience Office, Iqaluit, Canada
}

\section{Introduction}

Conodonts are phosphatic marine microfossils commonly preserved in Paleozoic carbonate rocks; they experience progressive, cumulative and irreversible colour changes upon heating and the changes have been experimentally calibrated as a colour alteration index (CAI). CAI values are time and temperature dependent, and permit us to estimate the maximum temperatures to which conodont-bearing rocks have been heated assuming a given time frame. Paleozoic carbonate xenoliths are entrained in resedimented kimberlite (RVK), pyroclastic (PK) and welded or agglutinated deposits (ACK) in many of the kimberlites from Chidliak, Baffin Island. The conodonts within the xenoliths have CAI values ranging from 1.5 to 8 (Zhang and Pell, 2014), which correlate strongly to the type of pipe infill (Figure 1). Thermal models for cooling of these pipes and synchronous heating of conodontbearing xenoliths indicate short time-spans for these events (Pell et al., 2015). In this study, we present data for CAI traverses across carbonate blocks up to $13.9 \mathrm{~m}$ in core length which show variations in CAI and allow us to further constrain the emplacement temperatures ( $\left.\mathrm{T}_{\mathrm{E}} \mathrm{s}\right)$ and cooling histories of the Chidliak kimberlite pipes.

\section{Observations}

Within some of the larger carbonate xenoliths, CAI values are zoned. The best example is a $13.9 \mathrm{~m}$ xenolith located near the margin of kimberlite $\mathrm{CH}-46$, a pipe with PK/ACK infill. This xenolith shows distinct concentric zoning, with lower CAI values in the core and higher ones towards its outer margins. The base of the xenolith, which is closer to the centre of the pipe, shows the highest CAI value and matches values for conodonts from a smaller adjacent xenolith (Figure 2). Based on the calibration presented in Pell et al. (2015), the CAI values in the core of this xenolith of 4-5, those surrounding the core of 5-6 and those at the base and in the adjacent small xenolith of 6.5-7 correspond to $\mathrm{T}$ 's of $365-625^{\circ} \mathrm{C}, 455-670{ }^{\circ} \mathrm{C}$ and $650-850{ }^{\circ} \mathrm{C}$, respectively. Another xenolith, $5.8 \mathrm{~m}$ in core length, also shows lower CAI values in its core (4) than towards its rims (5-6), while a third, $6.8 \mathrm{~m}$ xenolith, also may have similar zoning, but no conodonts were recovered from the material collected from the xenolith rims (possibly destroyed by high temperatures).

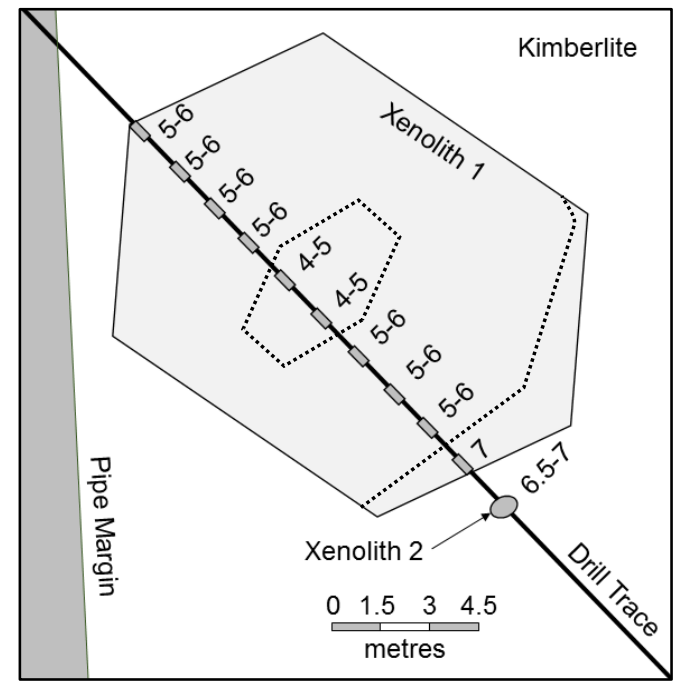

Figure 2. CAI traverse across a $13.9 \mathrm{~m}$ xenolith located proximal to the pipe margin in $\mathrm{CH}-46$. Xenoliths shown in grey with CAI data points darker. Dotted lines are schematic CAI zone boundaries. 
Two xenoliths, 2.6 and $2.9 \mathrm{~m}$ in core length, show a slight increase in CAI from top to base. One is from a PK-dominated pipe and records CAI values of 3-4 on the upper margin of the xenolith, 4 in the core and 4-5 on the lower margin. The second is from a PK/ACK infilled pipe and records CAI values of 6 throughout most of the xenolith, with CAI of 6-6.5 at its basal margin. Two xenoliths, 0.6 and 2.8 $\mathrm{m}$ in core length, both contained in PK, showed no variation in CAI (recording values of 5-6 throughout). Two xenoliths from kimberlite $\mathrm{CH}-45$ are anomalous: a $2 \mathrm{~m}$ xenolith shows higher CAI at its top than its base (6.5 and 5-6 respectively) and a $3.5 \mathrm{~m}$ xenolith has higher CAI values in its core (6.5-7) than those from its margins (5-6). CH-45 has two main types of infill; one is PK/RVK and contains the xenoliths and the other is a carbonate xenolith-free coherent kimberlite.

\section{Models}

A conductive cooling model was constructed for a $50 \mathrm{~m}$ diameter pipe with an emplacement temperature $\left(\mathrm{T}_{\mathrm{E}}\right)$ of $1000^{\circ} \mathrm{C}$ and an ambient $\mathrm{T}$ of $25^{\circ} \mathrm{C}$ for the host rock. Within 1 year the $\mathrm{T}$ at the pipe margin, and the peak temperature for the proximal wall rocks, is $\sim 475^{\circ} \mathrm{C}$. After a decade the pipe has a peak $\mathrm{T}$ of $\sim 400^{\circ} \mathrm{C}$ and the country rocks are heated by $\sim 100^{\circ} \mathrm{C}$ degrees up to $50 \mathrm{~m}$ from the contact. (Figure 3 ).
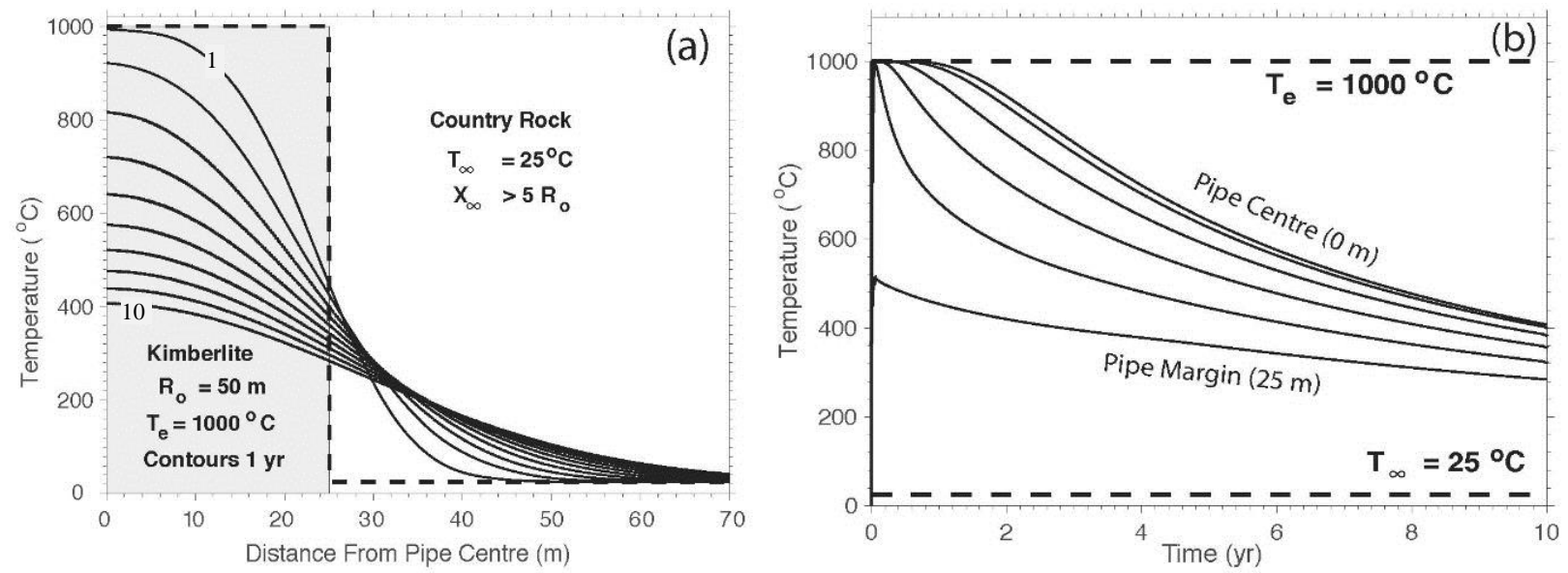

Figure 3. Conductive cooling model for a $50 \mathrm{~m}$ diameter pipe, modelled after $\mathrm{CH}-46$. Simulation uses an intial $\mathrm{T}$ of $1000^{\circ} \mathrm{C}$. (a) shows the temperature distributions from centre of kimberlite pipe $(0 \mathrm{~m})$ into the country rock (25- $70 \mathrm{~m}$ ) over a ten year period, using 1 year contours. (b) The same model simulation expressed as cooling curves ( $\mathrm{T}$ vs $\mathrm{t}$ ) for different positions in the pipe, contoured for increasing distances ( $5 \mathrm{~m}$ increments) from the pipe centre $(0 \mathrm{~m})$ until the margin of the pipe $(25 \mathrm{~m})$. In 10 years the pipe centre is at $\sim 400^{\circ} \mathrm{C}$ whilst the margin is at $\sim 300^{\circ} \mathrm{C}$. These curves are relevant to heating of the individual xenoliths as they define the TRANSIENT ambient $\mathrm{T}$ felt by the xenolith as it heats up.

Figure 4. Heating of $14 \mathrm{~m}$ diameter xenolith $\left(\mathrm{T}_{\text {ORIGINAL }}=25^{\circ} \mathrm{C}\right) 10 \mathrm{~m}$ from the wall of a $50 \mathrm{~m}$ diameter pipe $\left(\mathrm{T}_{\mathrm{E}}=1000^{\circ} \mathrm{C}\right)$ as it cools over 5 years is depicted. The solid black lines denote the cooling paths for the centre of the pipe and the margin (see Figure 3). Yellow stars and joining line denote the array of peak Ts experienced across the xenolith.

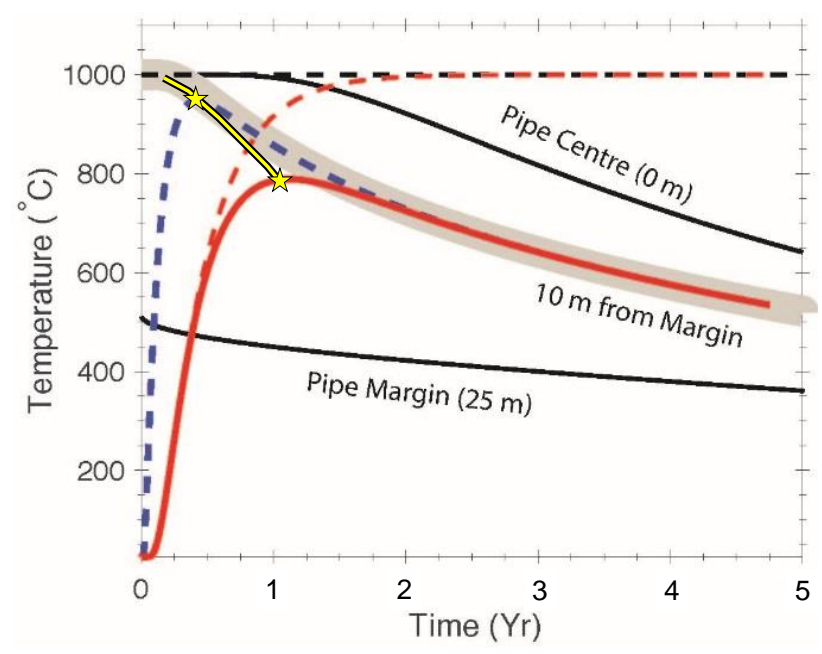

We have modelled the heating of a 14 m diameter xenolith ( $\mathrm{T}$ initial of $25^{\circ} \mathrm{C}$ ) located $10 \mathrm{~m}$ from the margin of a $50 \mathrm{~m}$ diameter pipe $\left(\mathrm{T}_{\mathrm{E}}\right.$ of $\left.1000^{\circ} \mathrm{C}\right)$ (heavy grey line; Figure 4). If the pipe remained at its $T_{E}$, the xenolith core would be heated along the dashed red line and, ultimately, would reach the pipe $\mathrm{T}_{\mathrm{E}}$ of $1000^{\circ} \mathrm{C}$. However, the pipe is cooling as the xenolith heats up. Thus, the core of the xenolith would be heated along the path described by the solid red line; heating up until it intersects the heavy grey line which denotes the transient cooling path of this part of the kimberlite pipe. Thereafter, the xenolith cools in tandem with the pipe. The blue dashed line denotes the thermal 
history of the same xenolith at $3 \mathrm{~m}$ from its rim (rather than the core). This demonstrates that the rim of the xenolith heats faster and to higher T's than its core and therefore different parts of the xenolith will record different peak Ts. If this xenolith was in the middle of the pipe, both core and rim could reach similar (high) peak T's that would be close to the $\mathrm{T}_{\mathrm{E}}$ of the pipe. Conversely, if this xenolith was at the margin of the pipe, the xenolith rim and core would lock in lower T's. It is implicit that smaller xenoliths will be be heated rapidly enough to record similar T's in rim and core, whilst large xenoliths may record quite different T's in their rims and cores.

We applied our model to explain the CAI zoning seen within the large xenolith depicted in Fig. 2. We modelled the peak temperatures reached within this xenolith from rim to core. The heating is

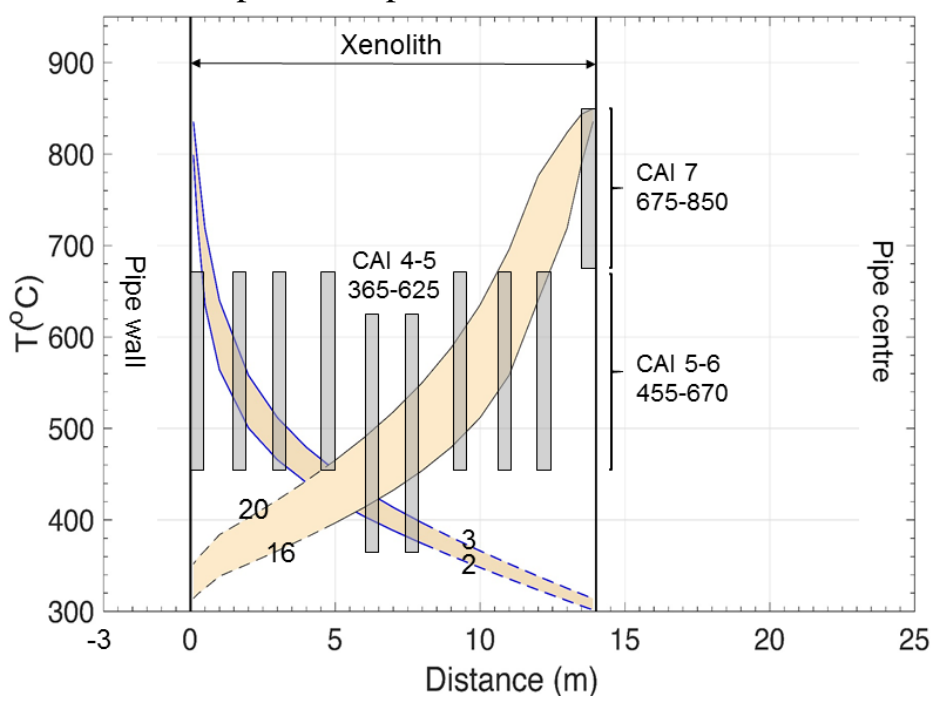
asymmetric because the large xenolith is situated very close to one margin of the pipe; that side of the xenolith (left in Fig. 5) is only exposed to 2 to $3 \mathrm{~m}$ of kimberlite. The other side (right) has a significant width of kimberlite available to heat it. Fig. 5 shows the best match to the actual data, which was obtained using a $\mathrm{T}_{\mathrm{E}}$ of $850^{\circ} \mathrm{C}$ for the host kimberlite. Lower pipe temperatures are incapable of matching the CAI values observed. Higher temperatures cannot be ruled out, but also do not match the CAI values as well as the model at $850^{\circ} \mathrm{C}$ does.

Figure 5. Model for asymmetric heating ot the large $(\sim 14 \mathrm{~m})$ xenolith shown in Fig. 2 in its actual position within the kimberlite. Grey bars are located where the CAI data was collected and they show the temperature range for the CAIs observed. The curves represent the arrays of peak Ts attained by the xenolith in its respective position (i.e. the line joining the yellow stars on Fig. 4) for the width of kimberlite against xenolith contacts ( 2 to $3 \mathrm{~m}$ on the left side, 16 to $20 \mathrm{~m}$ on the right).

\section{Discussion}

Four main types of CAI distribution in xenoliths was observed at Chidliak: 1) xenoliths that show the same CAI throughout; 2) xenoliths with lower CAI values in their cores than at their rims; 3) xenoliths that have CAIs that increase from one side to the opposite; and, 4) an unusual xenolith with higher CAI recorded in its core than at its rims. Our simple model shows that xenoliths that are unzoned or that display regular zoning, such as the xenolith depicted in Fig. 2 can be explained by in-place conductive heating of a xenolith by its host kimberlite. Our model, however, would not be applicable to situations where there the xenolith had experienced a more complex thermal history such as being entrained in a kimberlite magma during transport and subsequently being incorporated into a PK deposit, or to xenoliths emplaced within a thermally layered pipe infill (eg. interlayered PK/RVK or PK/CK) in which case heat transfer could be dominated by advection. The xenoliths with CAIs increasing from one side to the other have either experienced uneven heating, possibly in thermally layered pipe infill, or may be parts of larger, normally zoned xenoliths that have been broken prior to their currrent positioning. The one xenolith with higher CAI values in its apparent core requires an alternate explanation.

\section{References}

Pell, J., Russell, J.K. and Zhang, S., 2015. Kimberlite emplacement temperatures from condont geothermometry. Earth and Planetary Science Letters 411, 131-141.

Zhang, S. and Pell, J., 2014. Conodonts recovered from the carbonate xenoliths in the kimberlites confirm the Paleozoic cover on the Hall Peninsula, Nunavut. Can. J. of Earth Sci. 51, 142-155. 